\title{
Functional similarity of attached and free-living bacteria during freshwater phytoplankton blooms
}

\author{
Jakob Worm ${ }^{1, *}$, Kim Gustavson ${ }^{2}$, Kristine Garde ${ }^{2}$, Niels Henrik Borch ${ }^{3}$, \\ Morten Søndergaard ${ }^{3}$ \\ ${ }^{1}$ Department of Ecology, Royal Veterinary and Agricultural University, Thorvaldsensvej 40, \\ 1871 Frederiksberg (Copenhagen), Denmark \\ ${ }^{2}$ DHI Water and Environment, Agern allé 11, 2970 Hørsholm, Denmark \\ ${ }^{3}$ Freshwater Biological Laboratory, University of Copenhagen, Helsingørsgade 51, 3400 Hillerød, Denmark
}

\begin{abstract}
Phytoplankton blooms were created in freshwater enclosures to study the functional succession and diversification for attached $(>10 \mu \mathrm{m}$ size fraction) and free-living $(<10 \mu \mathrm{m}$ size fraction) assemblages of bacteria. Bacterial dynamics in abundance, production and enzyme activity was monitored by standard methods. The functional diversity with respect to sole carbon source utilization was assessed with Biolog GN plates inoculated with bacteria from the 2 size fractions. Moreover, bacterial isolates were screened for enzyme activity involved in the degradation of carbohydrates, chitin, protein and lipid. As the bloom proceeded, the functional diversity of attached and free-living bacteria appeared to be very similar. Most functional groups present in the free-living bacterial assemblage were also recovered attached to particulate matter. Additionally, the distribution of bacterial isolates with enzyme expression was similar with respect to 6 enzymes $(p>0.07)$, whereas 3 glucoside-bond cleaving enzymes were more frequent among the free-living isolates $(p<0.02)$. These results indicate that attached and free-living bacteria were functionally closely related and that their succession tended to converge during the phytoplankton bloom. Hence, bacteria attached to particulate matter are not necessarily functionally distinct and specialized for polymer hydrolysis relative to the free-living assemblage, though they are often anticipated to be different due to their close association with particulate polymers.
\end{abstract}

KEY WORDS: Attached bacteria $\cdot$ Particles $\cdot$ Phytoplankton bloom $\cdot$ Enzyme activity $\cdot$ Sole carbon source utilization $\cdot$ Functional diversity

Resale or republication not permitted without written consent of the publisher

\section{INTRODUCTION}

Pelagic bacteria consume organic matter equivalent to about half the primary production (Azam et al. 1983). Dissolved and particulate polymers are broken up by bacterial enzymes, and low molecular weight products are usually consumed as fast as they are produced (Chróst 1991, Smith et al. 1992, Søndergaard \& Middelboe 1995). These important functions involve combined actions of several groups of bacteria

*E-mail: jaw@kvl.dk
(Cottrell \& Kirchman 2000) because organic matter is a heterogeneous mixture of carbon sources (Münster \& Chróst 1990) and strains of bacteria are highly diverse in their metabolic preferences and capabilities (Martinez et al. 1996). A consequence of this heterogeneity is that growth conditions are not uniform for different groups of bacteria, and biotic and abiotic factors may promote successive changes in the community composition (Pernthaler et al. 1998).

Phytoplankton blooms fuel the water with new particulate and dissolved organic matter (Søndergaard et al. 2000a,b). In response, bacterial production and ectoenzyme activity increase (Chróst 1989) and an 
increasing number of bacteria attach to particulate matter (Middelboe et al. 1995, Smith et al. 1995, Riemann et al. 2000). Attached to particles, bacteria are faced with higher concentrations of organic polymers (Alldredge et al. 1993, Long \& Azam 1996) and they are less susceptible to predation by protozoa (Jürgens \& Güde 1994) than are free-living bacteria. Consortia of bacteria may also form more easily due to the spatial arrangement in the particle matrix (Watnick \& Kolter 2000). A selective nature of particulate matter is indicated by taxonomic differences of attached bacteria relative to the assemblages in the surrounding water (DeLong et al. 1993, Bidle \& Fletcher 1995, Acinas et al. 1997, 1999, Crump \& Armbrust 1999). Additionally, cell-specific enzyme activities for attached bacteria may exceed those of the free-living assemblage (Karner \& Herndl 1992, Smith et al. 1992, 1995, Worm \& Søndergaard 1998b, Riemann et al. 2000).

Bacterial dynamics during a phytoplankton bloom may reflect a relatively stable community being stimulated (Chróst 1991) as well as a more profound shift in the community composition (Martinez et al. 1996, Riemann et al. 2000). Riemann et al. (2000) found clear compositional changes in the bacterial community during the course of a phytoplankton bloom by use of denaturing gradient gel electrophoresis (DGGE) analysis of amplified bacterial ribosomal DNA. Following the culmination of the bloom, more phylotypes related to $\alpha$-Proteobacteria and Cytophagales appeared in the community. Functional changes in the bacterial community were also indicated by marked increases in growth and enzyme activity of bacteria attached to particulate matter ( $>1 \mu \mathrm{m}$ size fraction). The authors suggested that during the bloom new niches were created in association with particulate matter that selected for 'particle specialists', whose high expression of ectoenzyme activity facilitated their rapid growth on polymers (Riemann et al. 2000). Hence, it is possible that bacterial dynamics during a phytoplankton bloom reflects a succession where changes in the organic environment continuously select for specialized phenotypic traits. As yet, however, evidence for the proliferation of particle-specialist phenotypes are inferred mainly from enzyme assays of heterogeneous bacterial assemblages in size-fractionated samples. Surprisingly few studies of attached and free-living bacteria have addressed whether the 2 groups of bacteria differ with respect to their phenotypic properties, i.e. sole carbon source utilization (Hollibaugh et al. 2000) or enzyme profiles for individual strains of bacteria (Martinez et al. 1996).

In this study, we tested the hypothesis that a phytoplankton bloom leads to a divergence of attached and free-living bacteria, so that distributions of functional groups eventually differ in the 2 bacterial assem- blages. This hypothesis was tested in experimental phytoplankton blooms in freshwater enclosures. Bacterial dynamics was monitored by standard methods and the functional diversity was assessed with the Biolog GN assay (Biolog Inc., Hayward, CA, USA) (Garland \& Mills 1991). Furthermore, bacterial isolates were screened for their ability to produce enzymes that participate in the degradation of polymeric compounds.

\section{MATERIALS AND METHODS}

Experimental setup and sampling. During April 1999, 5001 mesocosms were established in lake Esrum, Denmark (Jonasson 1972). Mesocosms were filled with 4301 of $100 \mu \mathrm{m}$ filtered lake water. Phytoplankton blooms were created by additions of inorganic nitrogen, phosphorus and silicate (Nutrients) and eventually $150 \mu \mathrm{M}$ C glucose (Nutrients+C) to enrich the pool of biodegradable dissolved organic carbon about 4fold. For specific details about the experimental setup and nutrient dynamics see Søndergaard et al. (2000a). In the present study, we report on the microbial dynamics and functional diversity in enclosures termed Nutrients and Nutrients+C. Unfortunately, replicate enclosures for the 2 treatments were mixed with lake water early in the bloom.

The enclosures were thoroughly mixed before sampling. In the laboratory, water samples were kept at in situ temperatures $\left(5\right.$ to $\left.9^{\circ} \mathrm{C}\right)$. Samples were filtered by gravity through $10 \mu \mathrm{m}$ pore size Poretic filters (Osmonic Inc., Livermore, CA, USA) and particles retained on the filters were resuspended in $0.2 \mu \mathrm{m}$ pore size prefiltered water from the original water sample. Operationally, we designated bacteria retained by the $10 \mu \mathrm{m}$ pore-size filters as attached and bacteria in the filtrate $(<10 \mu \mathrm{m})$ as free living.

POC. POC was collected on duplicate precombusted $13 \mathrm{~mm} \mathrm{GF} / \mathrm{F}$ filters, dried at $40^{\circ} \mathrm{C}$ and measured as $\mathrm{CO}_{2}$ after dry combustion at $600^{\circ} \mathrm{C}$ (Søndergaard \& Middelboe 1993).

Bacterial abundance and production. Bacteria were stained with SYBR Green I nucleic acid stain (Molecular Probes, Leiden, The Netherlands), fixed with $1.8 \%$ glutaraldehyde (final concentration) and counted with a FACSCalibur flowcytometer (Becton Dickinson, Brøndby, Denmark) using $2 \mu \mathrm{m}$ fluorescent beads (Molecular Probes) as standards for the volume analyzed. Samples from the particle size fraction $(>10 \mu \mathrm{m})$ were sonicated (306 $\mu \mathrm{m}$ amplitude, 50\% duty cycle, 2 min, cooling in water bath) with a Sonifier 250 (Branson Ultrasonics Corp., Danbury, CO, USA) to disperse bacteria from the particles before the flow cytometer analysis (Velji \& Albright 1993). Dispersion of the bacteria was verified microscopically, and previous exper- 
iments have shown that fixed bacteria tolerate the sonication procedure (Worm \& Søndergaard 1998b).

Bacterial carbon production was estimated from leucine incorporation (Kirchman et al. 1985) and a factor of $3.6 \mathrm{~kg} \mathrm{C} \mathrm{mol}^{-1}$ was applied to convert from leucine to carbon equivalents (Simon \& Azam 1989). Bacterial cell production was estimated from thymidine incorporation (Fuhrman \& Azam 1980) and a conversion factor of $2 \times 10^{18}$ cells mol $^{-1}$ (Smits \& Riemann 1988) was applied. Unfiltered samples and $10 \mu \mathrm{m}$ pore size filtrates were incubated with either $100 \mathrm{nM}{ }^{3} \mathrm{H}$-leu or $20 \mathrm{nM}{ }^{3} \mathrm{H}$-thymidine (Amersham pharmacia biotech, Hørsholm, Denmark) for $1 \mathrm{~h}$ at in situ temperatures. Incubations were terminated by the addition of $5 \%$ trichloroacetic acid (final concentration) to precipitate macromolecules. Precipitated macromolecules were rinsed by 3 washes in 5\% trichloroacetic acid. Trichloroacetic acid was added to parallel blanks before ${ }^{3} \mathrm{H}$-leu or ${ }^{3} \mathrm{H}$-thymidine. Production of attached bacteria was calculated as the difference in incorporation rates between unfiltered samples and $10 \mu \mathrm{m}$ filtrates (free-living bacteria).

Enzyme activity in the enclosures. Activities of $\alpha$ glucosidase (4-methylumbelliferyl- $\alpha$-D-glucopyranoside), $\beta$-glucosidase (4-methylumbelliferyl- $\beta$-D-glucopyranoside), chitobiase (4-methylumbelliferyl- $N$ acetyl- $\beta$-D-glucosaminide dihydrate) and aminopeptidase (L-leucine-4-methyl-coumarinylamid hydrochloride) were measured with the fluorogenic model substrates from ICN as described by Hoppe (1993). Unfractionated samples, and 10 and $0.2 \mu \mathrm{m}$ pore size filtrates, were incubated at in situ temperatures with 0.5 mM enzyme substrate, except for L-leucine-4-methylcoumarinylamid, which was incubated at $0.25 \mathrm{mM}$ (final concentrations). Before fluorescence was read (Shimadzu RF-5001PC), samples with methylumbelliferylsubstrates were supplied with glycine-NaOH buffer $(\mathrm{pH}$ $10.4,0.1 \mathrm{mM}$ final concentration) to stabilize the fluorescence (Hoppe 1993). Hydrolysis rates were calculated from 2 consecutive measures of fluorescence following calibration of the fluorescence reading with standards of methylumbelliferone or 7-amino-4-methyl-coumarin (ICN). Initial kinetic experiments showed that rates of hydrolysis were constant along the incubation periods from 20 min to $4 \mathrm{~h}$, and that only aminopeptidase activity was measured at the saturation level.

Biolog community profiling. The functional diversity of attached and free-living bacteria was assessed from the sole carbon source utilization in Biolog GN microtiter plates, as proposed by Garland \& Mills (1991). Subsamples of $150 \mu \mathrm{l}$ of the size-fractionated samples were distributed in each well of duplicate Biolog plates and incubated at $20^{\circ} \mathrm{C}$ for $4 \mathrm{~d}$. The utilization of a carbon source was indicated by a color reaction, which was measured spectrophotometrically at $595 \mathrm{~nm}$ (ASYS HITECH). Maximum absorbance ranged between 1.500 and 2.000, and the threshold for a positive color response was set at 0.300. Carbon source utilization stabilized after $48 \mathrm{~h}$, and no changes in color developments were observed after 72 and $96 \mathrm{~h}$ (data not shown).

Cultivation and isolation of bacteria. Bacteria were cultivated as follows: size-fractionated samples were diluted in sterilized lake water $\left(121^{\circ} \mathrm{C}, 30 \mathrm{~min}\right)$, streaked on 10-fold diluted ZoBell $2216 \mathrm{E}$ agar medium

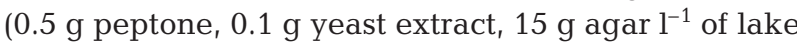
water) and incubated in the dark at $20^{\circ} \mathrm{C}$. Colony forming units (CFU) were repeatedly counted during the following 7 to 12 d. From each sampling (Days 1, 5, 8, 13 and 19), enclosure (Nutrients, Nutrients+C, 2 replicate enclosures) and fraction (>10 and <10 $\mu \mathrm{m}), 5$ colonies with distinct morphologies were picked and brought into pure culture by repeated streaking onto $(100 \%)$ ZoBell agar medium. Pure isolates were stored at $-80^{\circ} \mathrm{C}$ in equal volumes of liquid ZoBell medium and glycerol. About $25 \%$ of the strains failed to grow during the subculturing steps and 2 fungal isolates were omitted.

Enzyme activity of bacterial isolates. Bacterial isolates collected along the bloom were screened for their ability to produce enzymes that participate in the cleavage of starch, cellulose, chitin, protein and lipid. Isolates were incubated for $3 \mathrm{~d}$ in ZoBell medium with added potential inducers of the respective enzymes, i.e. $0.01 \%(\mathrm{w} / \mathrm{v})$ of starch (Merck), cellulose (Merck), chitin (Fluka) or casein (Sigma), or $0.01 \%$ (v/v) oleate (Sigma) before the enzyme assays were initiated.

Hydrolysis of polymers was identified from the formation of clearing zones on ZoBell agar supplied with starch (Smibert \& Krieg 1994), CM-cellulose, CMchitin (Loewe Biochemica $\mathrm{GmbH}$ ) or skimmed milk (Smibert \& Krieg 1994). Starch was stained with an iodine solution $\left(0.1 \% \mathrm{I}_{2}+0.3 \% \mathrm{KI}\right)$. Enzymes with hydrolytic affinities to terminal monomers were detected with fluorogenic model substrates as outlined above, including the lipase substrate 4-methylumbelliferyl-oletate (ICN, $0.05 \mathrm{mM}$ final concentration), except that fluorescence at 364/445 nm was detected in microtiter plates with an LS 50B Luminescence Spectrometer (Perkin Elmer Ltd) before and after 3 to $4 \mathrm{~h}$ incubation at $20^{\circ} \mathrm{C}$ in the dark. False negative results from the agar assays were scored from the absence of colonies on the agar surface and in some cases also from absence of aminopeptidase activity. For the liquid assays, increases in fluorescence 2-fold above the blank levels were scored as positive samples. Samples scored as (true) negative had a culture turbidity (optical density at $600 \mathrm{~nm}$ ) 2-fold above the blank samples, as measured with an EL312 Automated microplate reader (Bio-Tek Instruments, Inc.). 
Statistical analysis. Correlations between variables were estimated by linear regression of data with variance homogeneity and normally distributed residuals (Sokal \& Rohlf 1995). Carbon source utilization in the Biolog plates was analyzed by a non-metric multivariate method in which Bray-Curtis similarities (Bray \& Curtis 1957) are ordered by multidimensional scaling (MDS) (Clark \& Warwick 1994). Frequencies of isolates that tested positive and negative in enzyme expression were compared with Fisher's exact test or $\chi^{2}$ test (Sokal \& Rohlf 1995).

\section{RESULTS}

\section{The phytoplankton bloom}

During the first 2 wk of the phytoplankton bloom POC increased from $200 \mu \mathrm{M}$ to 659 (Nutrients) and 542 (Nutrients+C) $\mu \mathrm{M}$ and declined afterwards by more than $200 \mu \mathrm{M}$ relative to peak values (Fig. 1A). In parallel, the distribution of bacteria changed from a dominance of free-living bacteria during the first week toward a dominance of attached bacteria afterwards. This shift was directed by a steep decline in free-living

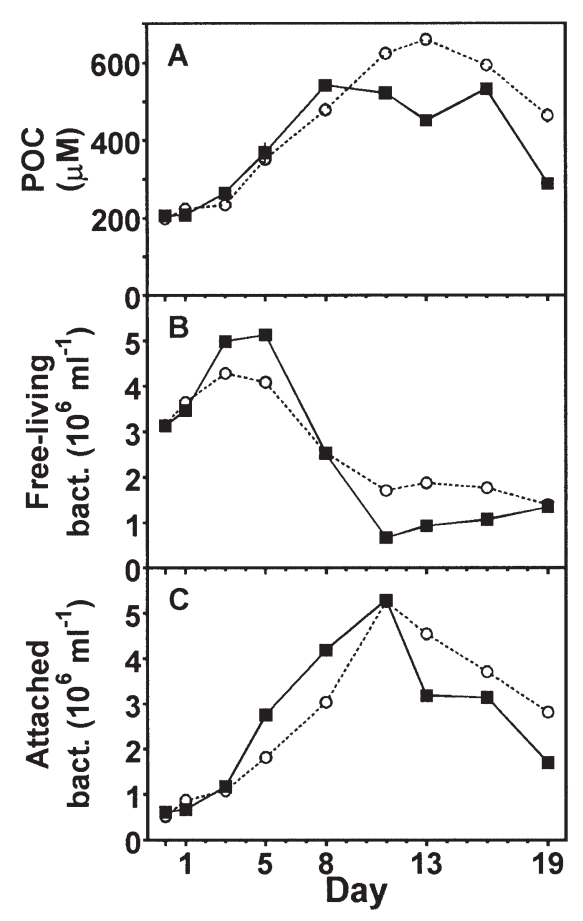

Fig. 1. (A) POC, and abundance of (B) free-living and (C) attached bacteria in Nutrients (inorganic nitrogen, phosphorus and silicate; circles) and Nutrients+C (supplemented with $150 \mu \mathrm{M} \mathrm{C}$ glucose; squares). The range of duplicate POC measures did not exceed the size of the symbols
Table 1. Bacterial counts in $10 \mu \mathrm{m}$ pore size filtrates (Day 16). During the filtration of $100 \mathrm{ml}$ lake water, 10 subsamples were collected for each $10 \mathrm{ml}$ filtered. Regression analysis of bacterial counts versus volume fraction: $y\left(10^{6}\right.$ cells ml $\left.^{-1}\right)=2.54 \times$ $10^{-4} \mathrm{x}+2.09(\mathrm{ml}$ filtered $) ; \mathrm{r}^{2}<0.01, \mathrm{p}=0.82$

\begin{tabular}{|cc|}
\hline $\begin{array}{c}\text { Volume fraction } \\
(\mathrm{ml})\end{array}$ & $\begin{array}{c}\text { Bacterial counts } \\
\left(10^{6}{\left.\text { cells } \mathrm{ml}^{-1}\right)}^{-1}\right.\end{array}$ \\
\hline $0-10$ & 2.04 \\
$10-20$ & 2.20 \\
$20-30$ & 2.06 \\
$30-40$ & 2.21 \\
$40-50$ & 2.11 \\
$50-60$ & 2.00 \\
$60-70$ & 2.10 \\
$70-80$ & 2.08 \\
$80-90$ & 2.00 \\
$90-100$ & 2.27 \\
\hline
\end{tabular}

bacteria between Days 5 and 11 (Fig. 1B); meanwhile, the abundance of attached bacteria increased (Fig. 1C) in close correlation with POC $\left(\mathrm{r}^{2}=0.94, \mathrm{p}<0.001\right)$. The shift in the distribution of bacteria was not a bias of the filtration procedure, i.e. that more free-living bacteria were retained on the $10 \mu \mathrm{m}$ pore size filters as particulate matter accumulated. Flow cytometric counts of bacteria were similar in 10 subsamples collected during the filtration of $100 \mathrm{ml}$ lake water (Table 1). Additionally, during the $19 \mathrm{~d}$ of sampling, flowcytometric counts of bacteria $\left(\mathrm{ml}^{-1}\right)$ in the free-living size-fraction $(y)$ accounted for $89 \%$ (SD $=7.6 \%$ ) of the counts in unfiltered samples $(x)$, and these counts were statistically similar $\left(\ln y=(1.04 \pm 0.03) \ln x-(0.75 \pm 0.43), r^{2}=\right.$ $0.97, \mathrm{p}<0.001$ ).

Enzyme activities in Nutrients and Nutrients+C increased nearly in parallel along the bloom and peaked at day 13 (Fig. 2). Only on Days 5 and 8 did $\alpha$ glucosidase and $\beta$-glucosidase activities in Nutrients $+C$ increase up to 4 -fold above those of Nutrients (Fig. 2A,B). In the same period bacterial abundance in

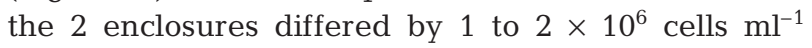
(Fig. 1B,C). This indicates that only transient and relatively limited effects were related to the initial glucose amendment. In the subsequent sections Nutrients and Nutrients $+\mathrm{C}$ are therefore considered mainly as replicates for the phytoplankton blooms.

Median estimates of cell-specific production indicated that attached bacteria tended to produce more carbon per cell division than did free-living bacteria (Table 2), but no trends were evident relative to days of sampling (data not shown). Median values of cell-specific enzyme activity were also higher for attached than for free-living bacteria, whereas median ratios of attached versus free-living activities ranged between 0.61 and 1.49 (Table 2). 


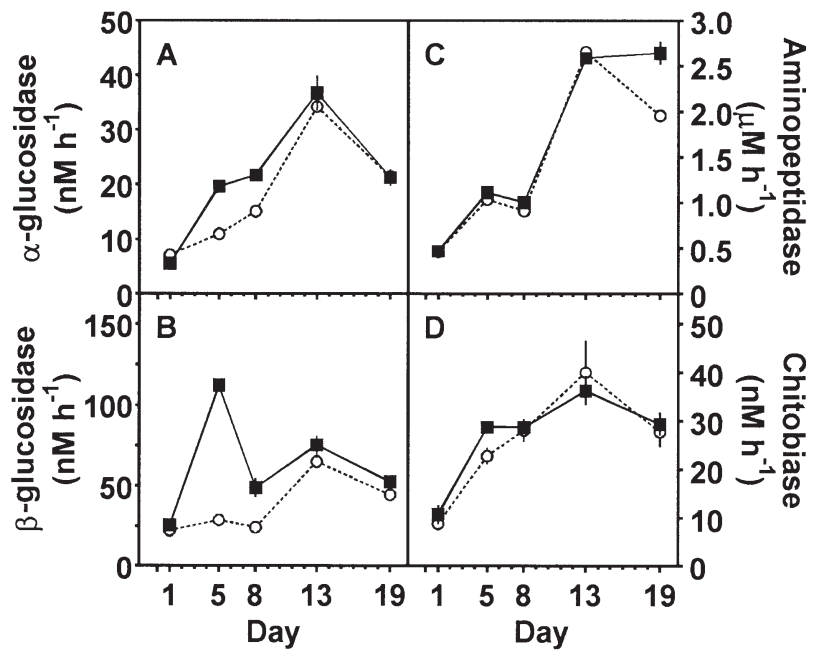

Fig. 2. Enzyme activity in unfiltered samples from Nutrients (circles) and Nutrients+C (squares), showing means and SD of triplicate measures

\section{Sole carbon source utilization}

Biolog plates were inoculated with attached and free-living bacteria to assess in more detail how functional groups of bacteria were distributed during the bloom. For free-living bacteria, the number of carbon sources utilized was nearly constant along the bloom and close to the median of 67 (Fig. 3A). Attached bacteria were consistently less versatile. On Days 1 and 5, attached bacteria utilized 15 to 30 fewer carbon sources than did free-living bacteria, but this difference reduced to 2 to 10 in the later stages of the bloom (Fig. 3B). In total, 80 carbon sources were utilized, of which 14 substrates were unique for free-living bac-

Table 2. Cell-specific production and enzyme activity for attached and free-living bacteria in Nutrients (inorganic nitrogen, phosphorus and silicate) and Nutrients+C (supplemented with $150 \mu \mathrm{M} \mathrm{C}$ glucose). Median values are shown with ranges in parentheses. Ratios of attached and free-living cell-specific activities are also shown as median values. ${ }^{3} \mathrm{H}-$ leu (3.5 $\left.\mathrm{kg} \mathrm{C} \mathrm{mol}^{-1}\right)$ (cell counts) $)^{-1}, \mathrm{n}=16 ;{ }^{\mp 3} \mathrm{H}$-thymidine $(2 \times$ $10^{18}$ cells mol $^{-1}$ ) (cell counts) ${ }^{-1}, \mathrm{n}=8{ }^{*}{ }^{\ddagger} 10^{-18} \mathrm{M} \mathrm{h}^{-1} \mathrm{cell}^{-1}, \mathrm{n}=10$

\begin{tabular}{|c|c|c|c|}
\hline & $\begin{array}{l}\text { Attached } \\
\text { (A) }\end{array}$ & $\begin{array}{l}\text { Free-living } \\
\text { (F) }\end{array}$ & $\begin{array}{c}\text { Ratio } \\
\text { A:F }\end{array}$ \\
\hline \multicolumn{4}{|c|}{ Cell-specific production } \\
\hline $\left.\mathrm{fg} C \mathrm{~d}^{-1^{*}}\right)$ & $10(3-19)$ & $4(1-16)$ & 2.25 \\
\hline Cells d $\mathrm{d}^{-1 \mathrm{f})}$ & $0.12(0.03-0.47)$ & $0.24(0.10-0.66)$ & 0.44 \\
\hline \multicolumn{4}{|c|}{ Cell-specific enzyme activity ${ }^{\ddagger}$} \\
\hline$\alpha$-glucosidase & $3.1(0-6)$ & $2.3(1-16)$ & 0.94 \\
\hline$\beta$-glucosidase & $9.5(4-18)$ & $7.2(1-31)$ & 1.49 \\
\hline Chitobiase & $5.1(3-11)$ & $3.2(0.1-11)$ & 0.61 \\
\hline Aminopeptidase & $227(146-692)$ & $137(88-1629)$ & 1.30 \\
\hline
\end{tabular}
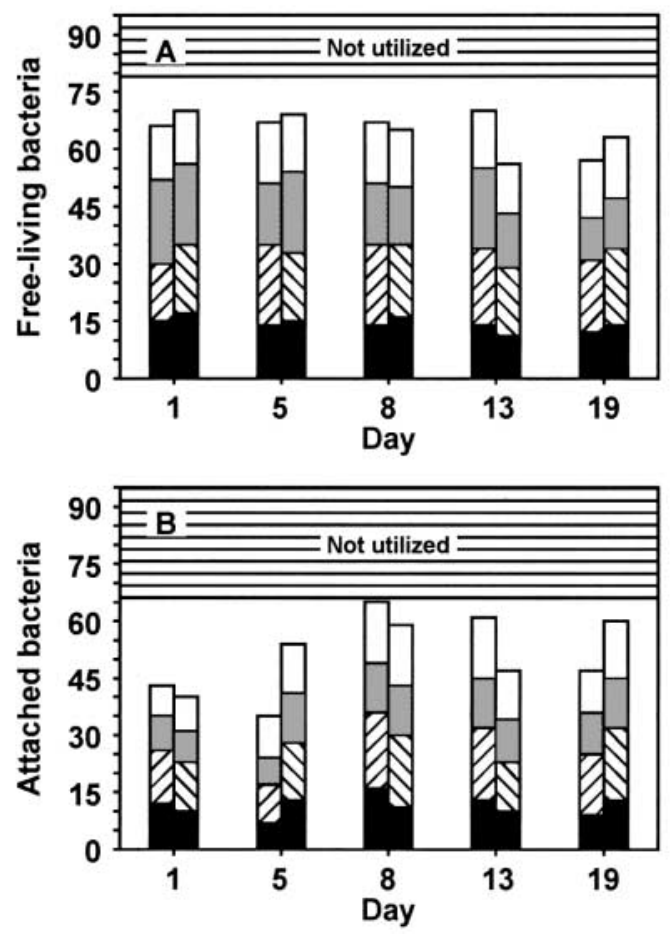

Fig. 3. Numbers of sole carbon sources utilized in the Biolog assays by (A) free-living and (B) attached bacteria in Nutrients (left) and Nutrients+C (right) during the diatom bloom. Bars are divided into 4 groups of carbon sources: amino acids, carbohydrates, carboxylic acids and others carbon sources (from top to bottom). Cross-hatched areas above the bars indicate the numbers of carbon sources not utilized in any of the fractionated samples $(n=20)$

teria. In contrast, no substrates were unique for attached bacteria, except for dextrin utilized in a single Biolog plate (Table 3).

All data for sole carbon source utilization are summarized in Fig. 4. By Day 1, all groups of bacteria are distant in the MDS plot (even replicates for attached bacteria), corresponding to relatively low degrees of similarity in carbon source utilization. On the subsequent day, however, attached as well as free-living bacteria in Nutrients and Nutrients+C are joined in the MDS plot (Fig. 4). This cluster of similarity tended to persist throughout the later stages of the bloom (Days 8,13 and 19).

Replicated Biolog assays generally clustered together in the MDS plot (Fig. 4). This indicates that inoculated bacteria were distributed homogeneously among the 95 micro-wells to generate reproducible patterns of carbon source utilization. One exception, however, is Day 1 for attached bacteria, where replicate Biolog plates showed a low degree of similarity (Fig. 4), possibly due to their association with particles and a relatively low number of culturable bacteria. In both size fractions there was a 10-fold increase in the 
Table 3. Sole carbon sources unique for attached and freeliving bacteria in Nutrients and Nutrients+C. Each carbon source includes 20 Biolog plates

\begin{tabular}{|c|c|c|}
\hline Category & Unique carbon sources & Frequency $(\%)$ \\
\hline \multicolumn{3}{|c|}{ Attached bacteria } \\
\hline Polymers & Dextrin & 5 \\
\hline \multicolumn{3}{|c|}{ Free-living bacteria } \\
\hline \multirow[t]{2}{*}{ Amines } & Pulrescine & 30 \\
\hline & Phenyl ethylamine & 10 \\
\hline \multirow[t]{2}{*}{ Amino acids } & Glucyl-L-glutamic acid & 10 \\
\hline & L-histidine & 5 \\
\hline Aromates & Thymidine & 25 \\
\hline \multirow[t]{8}{*}{ Carbohydrates } & $\beta$-methyl-D-glucoside & 35 \\
\hline & D-psicose & 25 \\
\hline & Lactulose & 20 \\
\hline & $N$-acetyl-D-glucosamine & 20 \\
\hline & D-raffinose & 15 \\
\hline & D-galactose & 15 \\
\hline & L-arabinose & 5 \\
\hline & Xylitol & 5 \\
\hline Esters & Methylpyruvate & 5 \\
\hline
\end{tabular}

culturable counts (CFU) relative to the direct cell counts from $<0.2 \%$ on Day 1 to 1 to $4 \%$ on Days 13 and 19 (data not shown).

\section{Expression of enzymes by attached and free-living isolates}

Strains that tested positive for enzyme activity were equally distributed among attached and free-living isolates with respect to cellulase, 2 chitinolytic, 2 proteolytic and 1 lipolytic enzymes ( $p$ > 0.08). In contrast,

Table 4. Frequencies of attached and free-living isolates with enzyme activity. Enzymes are listed in pairs according to the types of molecular bonds cleaved. Enzymes with affinity for terminal monomers are listed above those cleaving polymeric model substrates. "Probability that observed frequency deviations are random (Fisher's exact test or $\chi^{2}$-test)

\begin{tabular}{|lrrr|}
\hline Enzyme & \multicolumn{3}{c}{ Origin of isolates } \\
& $\begin{array}{c}\text { Attached } \\
\%(\mathrm{n})\end{array}$ & $\begin{array}{c}\text { Free-living } \\
\%(\mathrm{n})\end{array}$ & \\
\hline$\alpha$-glucosidase & $30(60)$ & $56(68)$ & 0.3 \\
Amylase & $23(64)$ & $43(75)$ & 1.7 \\
$\beta$-glucosidase & $29(75)$ & $56(70)$ & 0.1 \\
Cellulase & $4(52)$ & $15(62)$ & 10.3 \\
Chitobiase & $65(68)$ & $62(71)$ & 74.0 \\
Chitinase & $12(65)$ & $14(74)$ & 83.3 \\
Aminopeptidase & $100(71)$ & $100(82)$ & $>93.5$ \\
Proteinase & $67(60)$ & $51(70)$ & 7.9 \\
Lipase & $60(62)$ & $65(68)$ & 55.5 \\
\hline
\end{tabular}

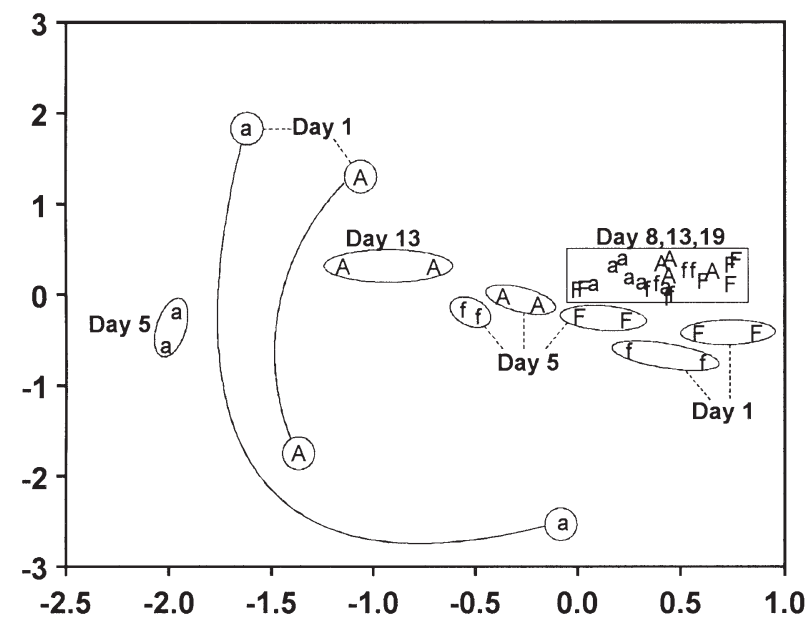

Fig. 4. Multidimensional scaled plot of similarities in sole carbon source utilization. Each letter represents 1 Biolog plate for either attached (Nutrients: $a$; Nutrients+C: A) or freeliving (Nutrients: $f_{;}$Nutrients+C: F) bacteria. The similarity is indicated by the distance between the letters, i.e., a short distance indicates a high similarity and less similar patterns in the sole carbon source utilization are more distantly plotted. A low stress coefficient of 0.114 indicates that the plot gave a good representation of the similarity pattern between samples

3 glycoside bond-cleaving enzymes were significantly less frequent $(p<0.02)$ for attached than for free-living isolates (Table 4). Additionally, enzymes with an affinity for cleaving polymers were consistently less frequent among isolates than were enzymes to cleave off terminal monomers from oligomer compounds. This difference was significant at $p<0.001$, except for the cleavage of $\alpha$-glucoside bonds ( $p>0.11$ ). For these analyses, isolates from Nutrients, Nutrients+C and 2 parallel enclosures were joined because frequencies of enzyme-producing isolates were all independent of the enclosure from which strains were originally isolated ( $p>0.34$ ). Selection for isolates with aminopeptidase activity cannot be ruled out, even though most amino acids were detected in the ZoBell medium by high pressure liquid chromatography equivalent to $51 \%(\mathrm{w} / \mathrm{w})$ of the protein content (N. O. G. Jørgensen, pers. comm.).

\section{DISCUSSION}

The present study tested the hypothesis that bacteria attached to particulate matter have phenotypic traits distinct from those of free-living bacteria during a freshwater phytoplankton bloom. We used $10 \mu \mathrm{m}$ pore size filters to separate attached and free-living bacteria. The microbial dynamics in the lake water was monitored directly by standard methods, and pheno- 
typic traits of the 2 groups of bacteria were assessed by culture-dependent assays.

The bacterial dynamics during the phytoplankton bloom included up to 10 -fold shifts in abundance (Fig. 1) and ectoenzyme activity (Fig. 2), in accordance with previous studies (Chróst 1989, Chróst et al. 1989, Middelboe et al. 1995, Smith et al. 1995, Riemann et al. 2000). Added glucose increased the concentration of labile organic carbon until Day 8, whereas accumulation of semi-labile dissolved organic carbon was similar in Nutrient and Nutrient+C (Søndergaard et al. 2000a). The addition of glucose may also explain a brief difference between the 2 enclosures in cell numbers (Fig. $1 B, C$ ) and the activity of $\alpha$-glucosidase and $\beta$-glucosidase (Fig. 2A,B). However, neither chitobiase and aminopeptidase activity (Fig. 2C,D) nor Biolog profiles indicated substantial differences between Nutrients and Nutrients+C (Figs 3 \& 4). Therefore, bacterial dynamics was related mainly to the phytoplankton blooms.

Direct measures of cell-specific production and enzyme activity ranged similarly for attached and freeliving bacteria (Table 2). The culture-dependent assays provided more details about the phenotypic traits of the 2 groups of bacteria. It appeared that attached and free-living bacteria were functionally closely related during the phytoplankton blooms. Most carbon sources utilized by free-living bacteria were also utilized by attached bacteria (Table 3). Patterns of sole carbon source utilization were fairly similar for the 2 groups of bacteria, as indicated by a cluster in the MDS plot during the second half of the bloom (Fig. 4). Finally, isolates with expression of enzymes did not tend to be more frequently attached than free-living (Table 4). Hence, particulate matter appeared not to be a strongly selective habitat relative to the bulk water. In comparison, Martinez et al. (1996) screened 44 marine snow and free-living isolates for enzyme activity in sterile filtered seawater and did not find systematical differences related to habitats, although bacteria associated with marine snow often express more enzyme activity per cell than bacteria in the surrounding water (Karner \& Herndl 1992). These results oppose the suggestion of Riemann et al. (2000) that fast-growing particle-specialist bacteria with distinct phenotypic traits invade and proliferate in association with particulate matter during a phytoplankton bloom (see 'Introduction').

In contrast to our results, Smith et al. (1995) and Riemann et al. (2000) found that cell-specific estimates of production and enzyme activity were systematically higher for attached than for free-living bacteria during marine phytoplankton blooms. This may indicate a difference between aquatic systems and successive shifts in bacterial communities. However, cell-specific rate measures are crude parameters to characterize bacteria because distributions of inactive, but counted bacteria may vary in the 2 size fractions (Simon 1985, Grossart \& Simon 1998a, Friedrich et al. 1999, Sherr et al. 1999). Moreover, their use of $1 \mu \mathrm{m}$ pore size filters to separate the 2 groups of bacteria makes direct comparison with our results uncertain because the homogeneity of the size fractions is expected to differ from that of $10 \mu \mathrm{m}$ pore size filters. Our use of $10 \mu \mathrm{m}$ pore size filters provided a more selective barrier to retain mainly attached bacteria and reduce the trapping of free-living bacteria in the particle fraction. The consequence of this choice was that some bacteria that were attached to small or fragile particles (Worm \& Søndergaard 1998a) might have passed through the filter. We considered this bias of minor importance to study the invasion and proliferation of bacteria on particles because attached bacteria are recruited from the freeliving assemblage, at least during the initial colonization of particles. Tests on the separation procedure indicated that the similarity between attached and free-living bacteria was not an obvious artifact of cross-contaminations between the 2 size fractions. Strong correlations for the abundance of attached bacteria versus POC $\left(\mathrm{r}^{2}=0.94\right)$ and bacterial counts in $<10 \mu \mathrm{m}$ pore size fraction versus unfiltered samples $\left(r^{2}=0.97\right)$ indicated a consistent separation of the 2 groups of bacteria. Therefore, bacterial counts in the free-living size fraction were not affected by clogging of the filter (Table 1).

The major advantage of the cultivation assays is that phenotypic traits of bacteria can be assessed with a specificity and versatility that more direct methods have not provided yet. However, bacteria recovered as colonies on ZoBell agar accounted for less than $5 \%$ of the direct count of bacteria and a comparable low recovery was likely in the Biolog assays (Amann et al. 1995). Moreover, cultivation of bacteria has been found to select more for $\gamma$-Proteobacteria than for $\alpha$ and $\beta$-Proteobacteria (Wagner et al. 1993, Kämpfer et al. 1996, Eilers et al. 2000). Therefore, the similarity between attached and free-living bacteria was not necessarily valid for the complete assemblage of bacteria. Interestingly, Riemann \& Winding (in press) used a DGGE analysis of ribosomal DNA to analyze the phylotypic composition of the attached and free-living bacteria from the same samples as those examined in the present study. They found broad compositional overlaps between the 2 size fractions. Since DGGE analysis is based on PCR amplification, the consistency with our data for cultured bacteria indicates that the similarity between attached and free-living bacteria has a relatively broad validity.

Similarities between attached and free-living bacteria are interesting because growth and survival are 
controlled distinctly for the 2 groups of bacteria (see Introduction). We speculate that a phenotypic divergence of the bacteria might have been suppressed by, e.g., exchange of cells (Hollibaugh et al. 2000, Riemann \& Winding in press) and dissolved matter (Smith et al. 1992, Grossart \& Simon 1998b) between the 2 habitats. Vetter et al. (1998) modeled the flux of hydrolysates produced by extracellular enzymes from bacteria associated with large aggregates (marine snow). Their model showed that 'expenses' of enzyme production were 'paid' in return by hydrolysates, though much hydrolysate was lost by diffusion to neighboring bacteria. Such cross-feeding may explain why bacteria without the ability to produce enzymes appeared not to be counter-selected when associated with particulate matter (Table 4).

Distinct enzymes are involved in the cleavage steps from polymers via oligomers to monomers (Cabib 1987, Kunji et al. 1996, Warren 1996). We found that polymer-cleaving enzymes were less frequently present in the strain collection than enzymes with affinities to cut terminal monomers from oligomeric compounds (Table 4). The differences were most pronounced for cellulase and chitinase, which were 4 - to 8 -fold less frequent among the isolates than $\beta$-glucosidase and chitobiase, respectively (Table 4). This indicates that a relatively narrow group of bacteria provided enzyme activity to break up larger polymers, whereas a broader range of community members were able to process the simpler hydrolysates before the final incorporation into biomass. Such consortial community structure may have important implications for the degradation of polymers, as recently shown in a simple model community (Worm et al. 2000). Therefore, we conclude that degradation of dissolved and particulate material involved an interplay among a broad range of bacteria, and many phenotypes appeared to be qualified for both attached and free states of living.

Acknowledgements. We thank Nils Willumsen, Anne Jacobsen and Merete Allerup for excellent technical assistance, Ole Nybroe and Lasse Riemann for valuable comments and discussions, and Henrik Christensen for the provision of a microplate fluorescence reader. This work was supported by grants from the Danish Natural Sciences Foundation and the Carlsberg Foundation to M.S. Additionally, DHI Water and Environment (K.G.) was supported by an EU MAST III contract (MAS3-CT97-0154-MIDAS).

\section{LITERATURE CITED}

Acinas SG, Rodríguez-Valera F, Pedrós-Alió C (1997) Spatial and temporal variation in marine bacterioplankton diversity as shown by RFLP fingerprinting of PCR amplified 16S rDNA. FEMS Microbiol Ecol 24:27-40
Acinas SG, Antón J, Rodríguez-Valera F (1999) Diversity of free-living and attached bacteria in offshore western Mediterranean waters as depicted by analysis of genes encoding 16S rRNA. Appl Environ Microbiol 65:514-522

Alldredge AL, Passow U, Logan BE (1993) The abundance and significance of a class of large, transparent organic particles in the ocean. Deep-Sea Res 40:1131-1140

Amann RI, Ludvig W, Schleifer KH (1995) Phylogenetic identification and in situ detection of individual microbial cells without cultivation. Microbiol Rev 59:143-169

Azam F, Fenchel T, Field JG, Gray JS, Meyer-Reil LA, Thingstad F (1983) The ecological role of water-column microbes in the sea. Mar Ecol Prog Ser 10:257-263

Bidle KD, Fletcher M (1995) Comparison of free-living and particle-associated bacterial communities in the Chesapeake Bay by stable low-molecular-weight RNA analysis. Appl Environ Microbiol 61:944-952

Bray JR, Curtis JT (1957) An ordination of the upland forest communities of southern Wisconsin. Ecol Monogr 27: 325-349

Cabib E (1987) The synthesis and degradation of chitin. Adv Enzymol 59:59-101

Chróst RJ (1989) Characterization and significance of $\beta$ glucosidase activity in lake water. Limnol Oceanogr 34: 660-672

Chróst RJ (1991) Microbial ectoenzymes in aquatic environments. In: Overbeck J, Chróst RJ (eds) Aquatic microbial ecology. Biochemical and molecular approaches. Springer-Verlag, New York, p 47-78

Chróst RJ, Münster U, Rai H, Albrecht D, Witzel PK, Overbeck J (1989) Photosynthetic production and exoenzymatic degradation of organic matter in the euphotic zone of a eutrophic lake. J Plankton Res 11:223-242

Clark KR, Warwick RM (1994) Change in marine communities: an approach to statistical analysis and interpretation. Natural Environment Research Council, Bournemouth

Cottrell MT, Kirchman DL (2000) Natural assemblages of marine Proteobacteria and members of the CytophagaFlavobacter cluster consuming low-and high-molecularweight dissolved organic matter. Appl Environ Microbiol 66:1692-1697

Crump BC, Armbrust EV (1999) Phylogenetic analysis of particle-attached and free-living bacterial communities in the Columbia River, its estuary, and the adjacent coastal ocean. Appl Environ Microbiol 65:3192-3204

DeLong EF, Franks DG, Alldredge AL (1993) Phylogenetic diversity of aggregate-attached vs. free-living marine bacterial assemblages. Limnol Oceanogr 38:924-934

Eilers H, Pernthaler J, Glöckner FO, Amann R (2000) Culturability and in situ abundance of pelagic bacteria from the North Sea. Appl Environ Microbiol 66:3044-3051

Friedrich U, Schallenberg M, Holliger C (1999) Pelagic bacteria-particle interactions and community-specific growth rates in four lakes along a trophic gradient. Microb Ecol $37: 49-61$

Fuhrman JA, Azam F (1980) Bacterioplankton secondary production estimates for coastal waters of British Columbia, Antarctica and California. Appl Environ Microbiol 39: 1085-1095

Garland JL, Mills AL (1991) Classification and characterization of heterotrophic microbial communities on the basis of patterns of community-level sole-carbon-source utilization. Appl Environ Microbiol 57:2351-2359

Grossart HP, Simon M (1998a) Bacterial colonization and microbial decomposition of limnetic organic aggregates (lake snow). Aquat Microb Ecol 15:127-140

Grossart HP, Simon M (1998b) Significance of limnetic 
organic aggregates (lake snow) for the sinking flux of particulate organic matter in a large lake. Aquat Microb Ecol 15:115-125

Hollibaugh JT, Wong PS, Murrell MC (2000) Similarity of particle-associated and free-living bacterial communities in northern San Francisco Bay, California. Aquat Microb Ecol 21:103-114

Hoppe H (1993) Use of flourogenic model substrates for extracellular enzyme activity (EEA) measurement of bacteria. In: Kemp PF, Sherr BF, Sherr EB, Cole JJ (eds) Handbook of methods in aquatic microbial ecology. Lewis Publisher, Boca Raton, p 423-431

Jonasson PM (1972) Ecology and production of the profundal benthos in relation to phytoplankton in Lake Esrum. Oikos Suppl 14:1-148

Jürgens K, Güde H (1994) The potential importance of grazing-resistant bacteria in planktonic systems. Mar Ecol Prog Ser 112:169-188

Kämpfer P, Erhart R, Beimfohr C, Böhringer J, Wagner M, Amann R (1996) Characterization of bacterial communities from activated sludge: culture dependent numerical identification versus in situ identification using group- and genus-specific rRNA-targeted oligonucleotide probes. Microb Ecol 32:101-121

Karner M, Herndl GJ (1992) Extracellular enzymatic activity and secondary production in free-living and marinesnow-associated bacteria. Mar Biol 113:341-347

Kirchman D, K'Nees E, Hodson R (1985) Leucine incorporation and its potential as a measure of protein synthesis by bacteria in natural aquatic systems. Appl Environ Microbiol 49:599-607

Kunji ERS, Mierau I, Hagting A, Poolman B, Konings WN (1996) The proteolytic systems of lactic acid bacteria. Antonie Van Leeuwenhoek 70:187-221

Long RA, Azam F (1996) Abundant protein-containing particles in the sea. Aquat Microb Ecol 10:213-221

Martinez J, Smith DC, Steward GF, Azam F (1996) Variability in ectoenzyme activities of pelagic marine bacteria and its significance for substrate processing in the sea. Aquat Microb Ecol 10:223-230

Middelboe M, Søndergaard M, Letarte Y, Borch NH (1995) Attached and free-living bacteria: production and polymer hydrolysis during a diatom bloom. Microb Ecol 29: 231-248

Münster U, Chróst RJ (1990) Origin, composition, and microbial utilization of dissolved organic matter. In: Overbeck J, Chróst RJ (eds) Aquatic microbial ecology. Biochemical and molecular approaches. Springer-Verlag, New York, p 8-46

Pernthaler J, Glöckner FO, Unterholzner S, Alfreider A, Psenner R, Amann R (1998) Seasonal community and population dynamics of pelagic bacteria and Archaea in a high mountain lake. Appl Environ Microbiol 64:4299-4306

Riemann L, Winding A (in press) Community dynamics of free-living and particle-associated bacterial assemblages during a freshwater phytoplankton bloom. Microb Ecol

Riemann L, Steward GF, Azam F (2000) Dynamics of bacterial community composition and activity during a mesocosm diatom bloom. Appl Environ Microbiol 66:578-587

Sherr BF, del Giorgio P, Sherr EB (1999) Estimating abundance and single-cell characteristics of respiring bacteria via the redox dye CTC. Aquat Microb Ecol 18:117-131

Simon M (1985) Specific uptake rates of amino acids by

Editorial responsibility: James Hollibaugh,

Athens, Georgia, USA attached and free-living bacteria in a mesotrophic lake. Appl Environ Microbiol 49:1254-1259

Simon M, Azam F (1989) Protein content and protein synthesis rates of planktonic marine bacteria. Mar Ecol Prog Ser 51:201-213

Smibert RM, Krieg NR (1994) Phenotypic characterization. In: Gerhardt P, Murray RGE, Wood WA, Krieg NR (eds) Methods for general and molecular bacteriology. American Society for Microbiology, Washington, p 607-654

Smith DC, Simon M, Alldredge AL, Azam F (1992) Intense hydrolytic enzyme activity on marine aggregates and implications for rapid particle dissolution. Nature 359: 139-142

Smith DC, Steward GF, Long RA, Azam F (1995) Bacterial mediation of carbon fluxes during a diatom bloom in a mesocosm. Deep-Sea Res 42:75-97

Smits JD, Riemann B (1988) Calculation of cell production from $\left[{ }^{3} \mathrm{H}\right]$ thymidine incorporation with freshwater bacteria. Appl Environ Microbiol 54:2213-2219

Sokal RG, Rohlf FJ (1995) Biometry. WH Freemann and Company, New York

Søndergaard M, Middelboe M (1993) Measurements of particulate organic carbon: a note on the use of glass fiber (GF/F) and Anodisc ${ }^{\circledR}$ filters. Archiv Hydrobiol 127:73-85

Søndergaard M, Middelboe M (1995) A cross-system analysis of labile dissolved organic carbon. Mar Ecol Prog Ser 118: 283-294

Søndergaard M, Borch NH, Riemann B (2000a) Dynamics of biodegradable DOC produced by freshwater plankton communities. Aquat Microb Ecol 23:73-83

Søndergaard M, Williams PJIB, Cauwet G, Riemann B, Robinson C, Terzic S, Malcolm E, Woodward S, Worm J (2000b) Net accumulation and flux of dissolved organic carbon and dissolved organic nitrogen in marine plankton communities. Limnol Oceanogr 45:1097-1111

Velji MI, Albright LJ (1993) Improved samples preparation for enumeration of aggregated aquatic substrate bacteria. In: Kemp PF, Sherr BF, Sherr EB, Cole JJ (eds) Handbook of methods in aquatic microbial ecology. Lewis Publisher, Boca Raton, p 139-142

Vetter YA, Deming JW, Jumars PA, Krieger-Brockett BB (1998) A predictive model of bacterial foraging by means of freely released extracellular enzymes. Microb Ecol 36: 75-92

Wagner M, Amann R, Lemmer H, Schleifer KH (1993) Probing activated sludge with oligonucleotides specific for Proteobacteria: inadequacy of culture-dependent methods for describing microbial community structure. Appl Environ Microbiol 59:1520-1525

Warren RAJ (1996) Microbial hydrolysis of polysaccharides Annu Rev Microbiol 50:183-212

Watnick P, Kolter R (2000) Biofilm, city of microbes. J Bacteriol 182:2675-2679

Worm J, Søndergaard M (1998a) Alcian blue-stained particles in a eutrophic lake. J Plankton Res 20:179-186

Worm J, Søndergaard M (1998b) Dynamics of heterotrophic bacteria attached to Microcystis spp. (Cyanobacteria). Aquat Microb Ecol 14:19-28

Worm J, Jensen LE, Hansen TS, Søndergaard M, Nybroe O (2000) Interactions between proteolytic and non-proteolytic Pseudomonas fluorescens affect protein degradation in a model community. FEMS Microbiol Ecol 32: 103-109

Submitted: December 1, 2001; Accepted: July 3, 2001

Proofs received from author(s): August 7, 2001 